\title{
Services Inputs and Firm Productivity in Sub-Saharan Africa Evidence from Firm-Level Data
}

\author{
Jens Matthias Arnold* \\ Aaditya Mattoo ${ }^{* *}$ \\ Gaia Narciso $^{* * *}$
}

\begin{abstract}
This paper investigates the relationship between the productivity of African manufacturing firms and their access to services inputs. We use data from the World Bank Enterprise Survey for over 1,000 firms in 10 Sub-Saharan African countries to calculate the total factor productivity of firms. The Enterprise Surveys also contain unique measures of firms' access to communications, electricity and financial services. The availability of these measures at the firm level, both as subjective and objective indicators, allows us to exploit the variation in services performance at the sub-national regional level. Furthermore, by using the regional variation in services performance, we are also able to address concerns about the possible endogeneity of the services variables. Our results show a significant and positive relationship between firm productivity and service performance in all three services sectors analyzed. The paper thus provides support for the argument that improvements in services industries contribute to enhancing the performance of downstream economic activities, and thus are an essential element of a strategy for promoting growth and reducing poverty.
\end{abstract}

Keywords: services liberalization, productivity

JEL Codes: L8, F2, D24

World Bank Policy Research Working Paper 4048, November 2006

The Policy Research Working Paper Series disseminates the findings of work in progress to encourage the exchange of ideas about development issues. An objective of the series is to get the findings out quickly, even if the presentations are less than fully polished. The papers carry the names of the authors and should be cited accordingly. The findings, interpretations, and conclusions expressed in this paper are entirely those of the authors. They do not necessarily represent the view of the World Bank, its Executive Directors, or the countries they represent. Policy Research Working Papers are available online at http://econ.worldbank.org.

\footnotetext{
*Organisation for Economic Co-operation and Development, 2, rue Andre Pascal, 75116 Paris, France. Email: jens.arnold@oecd.org. **World Bank, 1818 H Street, NW; MSN MC3-303; Washington, DC, 20433. Email: amattoo@worldbank.org. *** Bocconi University, Via Sarfatti 25, Milano, Italy. Email: gaia.narciso@unibocconi.it. This paper is part of the World Bank's research program on trade in services, which is supported in part by the United Kingdom's Department for International Development.
} 


\section{Introduction}

Services inputs play an important role in many economic activities. It is difficult to think of any firm in either industry or services that would not rely on telecommunications services, financial services, or energy. Yet, access to reliable services of adequate quality varies substantially across countries, and often presents difficulties for firms in Sub-Saharan Africa.

The tradability of services inputs across national and even regional borders is quite limited, in spite of the increasing scope for electronic delivery. Whereas physical inputs can be imported from other parts of the country or world, firms are more reliant on the state of locally produced services inputs in telecommunications, banking and electricity distribution, the three services on which we focus in this paper. As a result, difficulties in procuring adequate services inputs locally may constrain firm performance.

There are several channels through which inadequate services inputs could affect the performance of firms. If telecommunication services are unreliable, firms may find it difficult to communicate and coordinate with clients and suppliers, and lose staff time in the process. Difficulties in obtaining credit or other inadequacies in banking services may prevent a firm from exploiting productivity-enhancing investment opportunities, and create unnecessary friction in the financial functioning of the firm. Inadequacies in power provision may disrupt the production process, cause productive assets to lie idle and thus decrease productivity.

Many African countries have been engaged in trade liberalization in recent years. But successful participation by African producers in export markets may be constrained by the difficulty in accessing services inputs at home. In fact, unless African firms are able to access services inputs of competitive quality and prices, they may find it difficult to compete even in the domestic market. In many African countries, firm expenses on services inputs constitute a considerably larger fraction of total costs than in other parts of the world, and often dwarf labor costs (Eifert et al. 2005). Hence any improvement in the conditions at which these services inputs can be purchased is likely to have at least as much of an influence on total costs as a change in labor costs.

This paper investigates the extent to which the productivity of African manufacturing firms is related to difficulties in procuring services inputs, using firm-level data from 10 Sub-Saharan African countries. The source of this data is the World Bank Enterprise Surveys, which include over 1,000 firms in Ethiopia, Kenya, Madagascar, Mali, Mauritius, Senegal, South Africa, Tanzania, Uganda and Zambia. We use information on firm inputs and outputs to calculate total factor productivity of firms. The Enterprise Surveys also contain unique measures of the performance of communications, electricity and financial services. The availability of these measures at the firm level, both as subjective and objective indicators, allows us to exploit the variation in services performance at the sub-national regional level. By using the regional variation of services performance, we are also able to address possible endogeneity concerns about the services variable.

Our results show a significant positive association between the performance of manufacturing firms in a region and indicators of the availability of services in the region. The findings are consistent with the view that services matter for the productivity of firms, and provide evidence 
of the relevance of services sectors beyond the boundaries of the sectors themselves. As the ILO World Employment Report 2004-05 states, "bridging the global productivity divide is essential for fighting poverty and stimulating growth in both output and decent and productive employment". Productivity is a necessary condition for creating incomes that allow people to escape from poverty. This paper strengthens the argument that reforming services industries can contribute to enhancing the productivity of downstream economic activities, and thus be an essential element of a strategy for promoting growth and reducing poverty.

\section{Related Literature}

There is a growing body of evidence of the relevance of services sectors for growth and productivity. At the aggregate level, Eschenbach and Hoekman (2006) document a positive correlation between the extent of services liberalization and economic growth in transition countries during the 1990-2004 period. Mattoo, Rathindran and Subramanian (2006) present econometric evidence from a sample of 60 countries over the 1990-1999 period that openness in the financial and telecommunications sectors influences long-run growth performance. At the micro level, Arnold, Javorcik and Mattoo (2006) provide evidence for a positive link between services liberalization and downstream manufacturing performance for the case of the Czech Republic. ${ }^{1}$

To the best of our knowledge, the role of services inputs in Sub-Saharan Africa has not yet been analyzed rigorously in the literature. Most of the literature on the performance of production establishments in the region has focused on the relationship between export status and performance (Van Biesebroek 2005, Bigsten et. al. 2004, Mengistae and Patillo 2004). Clarke (2005) investigates the relationship between policy variables and the export performance of African firms, and finds that restrictive trade and customs regulations appear to discourage exporting.

Tybout (2000) reviews the performance of manufacturing firms in developing countries and identifies the following reasons for the poor performance of many developing-country establishments compared to global best practice: a lack of market size (which may be aggravated by insufficient transport services), a lack of human capital, and difficulties in accessing manufactured inputs and infrastructure services at competitive prices and quality. The objective of this paper is to assess the significance of the last variable, access to infrastructure services.

Finally, as noted above, Eifert et al. (2005) analyze the share of "indirect" costs for firms in 42 countries. Most of these indirect costs are attributable to services-related inputs into production - energy, transport, telecom, water, insurance, marketing, travel, independent professionals and accounting. They find that in countries such as China, India, Nicaragua, Bangladesh and Morocco, indirect costs account for 13-15 percent of total costs, around half the level of labor

\footnotetext{
${ }^{1}$ A related literature considers the importance of services reform for goods trade. Fink, Mattoo and Neagu (2005) show that communication costs matter for export performance for certain goods, and Freund and Weinhold (2002) find a trade-enhancing effect of internet connectivity.
} 
costs. In most African countries, indirect costs average as high as 20-30 percent of total costs, often dwarfing labor costs.

\section{Data and Empirical Strategy}

Our establishment-level data come from the World Bank Enterprise Surveys. Data from these surveys are available for a cross-section of firms from 10 Sub-Saharan African countries which were surveyed following the same methodology. The countries are Ethiopia, Kenya, Madagascar, Mali, Mauritius, Senegal, South Africa, Tanzania, Uganda and Zambia, and the surveys were undertaken between 2001 and 2005.

The Enterprise Survey Data contain detailed information on output and production inputs, which we transform into real values using the respective GDP deflator and then convert into US dollars using the yearly average exchange rate. We estimate total factor productivity (TFP) as the residual of the Cobb-Douglas production function in equation 1, with real output as a function of capital, labor and intermediate inputs. Particular attention was given to the capital variable. In firm-level data sets, this is usually the variable which creates the strongest concerns regarding correct measurement, because firms have an incentive to overstate depreciation and understate the book value of their physical capital for tax reasons. To avoid this problem, the Enterprise Surveys contain a question about the current resale value of the machinery and equipment if the firm had to sell it the next day, and we use this information to estimate the value of the capital stock. We estimate the production function as

$y_{i}=\alpha_{s}+\beta_{s} \cdot l_{i}+\gamma_{s} \cdot k_{i}+\delta_{s} \cdot m_{i}+\mu_{i}$

where $y_{i}$ represents real firm output, $l_{i}$ is labor, $k_{i}$ capital and $m_{i}$ intermediate inputs. The estimated coefficients vary at the level of each manufacturing industry s, which include food and beverages, textiles and garments, chemicals and pharmaceuticals, metals and metal products, non-metallic mineral products as well as wood products and furniture. ${ }^{2}$ The parameters of the production function (1) are identified using two approaches: the first is an ordinary least square estimator, and the second is the semi-parametric estimator suggested by Olley and Pakes (1996). The latter uses the firm's investment behavior to control for a possible estimation bias that may arise if a firm makes its input choices contingent on an unobserved productivity shock affecting $\mu_{\mathrm{i} .}{ }^{3}$

The second building block of our analysis is information about the performance of services sectors, which is also available from the Enterprise Surveys. The surveys contain both subjective and objective measures of local services performance. The subjective measures are firms' valuation on a scale from 1 to 5 as to how much of a constraint they consider electricity, telecommunications and access to finance for their businesses. The objective measures come

\footnotetext{
${ }^{2}$ Unfortunately, we were not able to obtain reasonable production function estimates for the chemicals and pharmaceuticals industry using the Olley and Pakes approach, and had to drop this sector from the regressions when we use the TFP estimates originating from that procedure.

${ }^{3}$ Other applications of the Olley/Pakes procedure which contain detailed descriptions of the methodology can be found in Pavenik (2002) or Arnold and Hussinger (2006).
} 
from questions about the delay involved in having a new phone line installed, the number of days required to clear a domestic or foreign money wire, the number of days with power outages in the last year, and whether a firm has chosen to install its own power generator. Table 1 shows descriptive statistics of these measures by country.

Table 1. Descriptive Statistics of the Services Performance Measures

Objective measures

\begin{tabular}{|c|c|c|c|c|c|c|c|c|c|c|c|c|c|c|c|}
\hline \multirow[b]{2}{*}{ Country } & \multicolumn{3}{|c|}{$\begin{array}{l}\text { Number of days to } \\
\text { obtain a telephone } \\
\text { connection }\end{array}$} & \multicolumn{3}{|c|}{$\begin{array}{l}\text { Number of days to } \\
\text { clear a foreign } \\
\text { currency wire }\end{array}$} & \multicolumn{3}{|c|}{$\begin{array}{l}\text { Number of days to } \\
\text { clear a domestic } \\
\text { currency wire }\end{array}$} & \multicolumn{3}{|c|}{$\begin{array}{l}\text { Number of days of } \\
\text { power outages in a } \\
\text { year }\end{array}$} & \multicolumn{3}{|c|}{$\begin{array}{l}\text { Percentage of firms } \\
\text { owning a generator }\end{array}$} \\
\hline & mean & p50 & $\mathrm{N}$. & mean & p50 & $\mathrm{N}$. & mean & p50 & $\mathrm{N}$. & mean & p50 & $\mathrm{N}$. & mean & p50 & $\mathrm{N}$. \\
\hline Ethiopia & 155 & 90 & 147 & 7.9 & 5 & 50 & 2.1 & 1 & 181 & & & 0 & $17 \%$ & 0 & 418 \\
\hline Kenya & 99 & 42 & 171 & & & 0 & & & 0 & 84 & 40 & 247 & $71 \%$ & 1 & 278 \\
\hline Madagascar & 64 & 30 & 69 & 7.5 & 5 & 183 & 3.5 & 2 & 256 & 78 & 30 & 240 & $22 \%$ & 0 & 293 \\
\hline Mauritius & 22 & 10 & 89 & 3.5 & 3 & 171 & 1.5 & 1 & 166 & 8 & 4 & 199 & $39 \%$ & 0 & 204 \\
\hline South Africa & 8 & 5 & 241 & 3.6 & 3 & 414 & 2.5 & 2 & 522 & 6 & 4 & 384 & $9 \%$ & 0 & 603 \\
\hline Tanzania & 23 & 14 & 68 & 6.3 & 4 & 93 & 4.4 & 3 & 139 & 67 & 48 & 211 & $55 \%$ & 1 & 271 \\
\hline Uganda & 33 & 7 & 130 & & & 0 & & & 0 & 71 & 30 & 268 & $36 \%$ & 0 & 300 \\
\hline Zambia & 89 & 30 & 20 & 4.6 & 4 & 161 & 2.4 & 2 & 144 & 38 & 17.5 & 204 & $39 \%$ & 0 & 205 \\
\hline
\end{tabular}

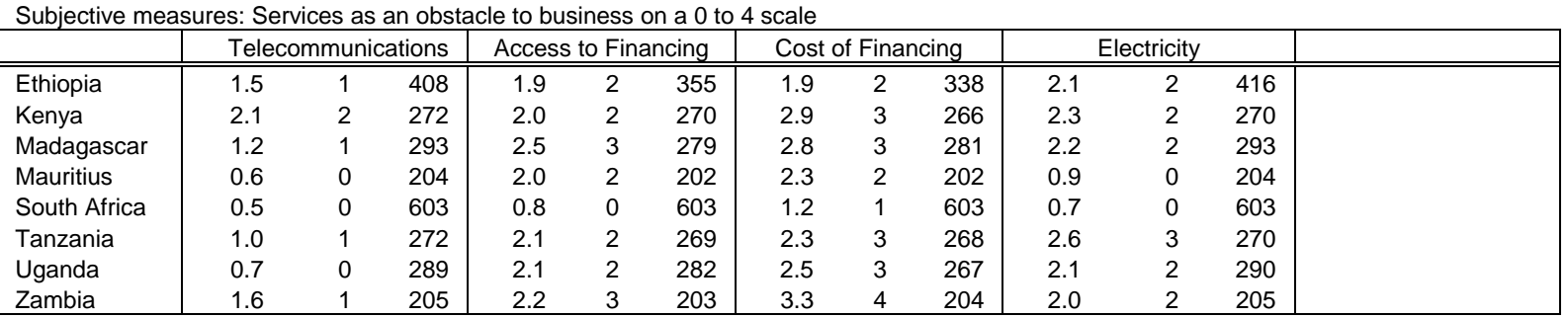

While the World Bank Enterprise Surveys have the advantage of containing information about services performance at a more disaggregated level than the country level, the fact that this information comes from the same firms whose performance we examine also creates challenges.

The challenges in this exercise are twofold. Relating a firm's performance to its own perceptions of, or even its own measurable experiences with, access to services would create concerns about endogeneity. Perceptions are likely to be influenced by success, and a more efficient firm may be more efficient because of particular characteristics that also affect the treatment it receives from services providers, like size and the resourcefulness of the manager. These issues make a one-to-one juxtaposition at the level of the firm an unattractive empirical strategy. At the other extreme, aggregating all the information to the country level would make it impossible to control for other country-specific differences in governance, institutions, business climate or geography in a cross-section. And it would leave the unique variation at the sub-national level unexploited.

Our empirical strategy is thus to go the middle way by exploiting the regional variation within countries. Rather than using the individual firm's responses to the services-related questions on the right hand side, we aggregate these responses up to regional averages. This reduces considerably the influence that an individual firm's performance can have on the value of a right hand side variable. At the same time, regions within a country share all the possible 
unobservable influences that are determined at the country level, and introducing country fixedeffects allows us to capture these unobserved differences.

In order for our strategy to be reasonable, we require a sufficiently large number of observations per region to bring down the influence that an individual firm's response can have on the right hand side variable, and sufficiently large number of regions within a country for the country fixed-effects to have any meaning. These requirements come at the cost of having to exclude Senegal and Mali from our regressions, because in these two countries, almost $90 \%$ of the firms in our sample are located in the capital region, leaving little regional variation to be exploited. In the other countries, we find a reasonable distribution of firms across regions, whose number ranges from 3 in Uganda to 8 in Ethiopia.

Our empirical specification in equation 2 is quite simple: We regress firm TFP on measures for the performance of services, aggregated to regional averages. Additional controls in our regressions are fixed effects for countries and for industries, as well as a vector of covariates X that have been typically recognized as relevant for firm performance in the literature. These are export status, firm size (by means of an indicator for firms with more than 50 employees), and domestic vs. foreign ownership. For the latter, we follow the standard definition used by the International Monetary Fund of considering firms with at least 10\% foreign capital share foreign-owned. Finally, since location in the capital region may have advantages that go beyond differences in services provision, we also control for location in a nation's capital.

$$
\mu_{i}=\varphi+\lambda \cdot \text { Services_performance }_{\text {reg }}+\pi \cdot X+D_{\text {country }} \cdot \kappa+D_{\text {ind }} \cdot \vartheta+\varepsilon_{i}
$$

With respect to our services performance variables, we generally prefer the objective measures to the subjective ones, because we believe that the former are less subject to the possible endogeneity of perceptions. It turns out, however, that the respective subjective and objective measures are highly correlated, as can be seen from some simple descriptive regressions presented in the appendix. This gives us reason to believe that we are capturing differences in access to services across African regions in a meaningful way. We will first enter the performance measures for the three services sectors separately into equation (2), and then present the results of a model containing measures for all three at the same time.

\section{Results}

\section{Telecommunications}

We begin with the telecommunications sector. Table 2 displays the relationship between manufacturing firm productivity and the performance for this sector, for which the available objective measure is the number of days required to obtain a new phone connection. We interpret this variable as a broad indicator of sector performance. In countries with competitive and efficient telecommunications markets, getting a new phone line connected tends to be a matter of at most a few days, whereas in countries with inefficient public monopolies, there tend to be long waiting lists for phone lines (the median wait time in Ethiopia was 90 days, for example). 
The results in table 2 show a significant relationship between telecommunications performance and firm productivity in downstream manufacturing sectors. The relationship is significant at the $1 \%$ level for both the total factor productivities estimated using ordinary least squares as well as the semi-parametric estimator. Good access to telecommunications inputs (expressed by a low value on our measure) is associated with higher performance of manufacturing firms.

With respect to the covariates, we also find foreign-owned companies to be significantly more productive than domestically-owned ones, which is in line with the literature on foreign direct investment (see Arnold and Javorcik 2006 for a comprehensive treatment of this issue for the case of Indonesia). ${ }^{4}$

Table 2: Total Factor Productivity and Telecommunications

\begin{tabular}{|c|c|c|}
\hline TFP estimation procedure: & OLS & Olley/Pakes \\
\hline Days required to get a phone line & $\begin{array}{c}-0.002^{* * *} \\
{[0.001]}\end{array}$ & $\begin{array}{l}-0.002^{* *} \\
{[0.001]}\end{array}$ \\
\hline Exporter & $\begin{array}{c}-0.004 \\
{[0.044]}\end{array}$ & $\begin{array}{c}0.073 \\
{[0.052]}\end{array}$ \\
\hline Age of the firm & $\begin{array}{c}0.002 \\
{[0.019]}\end{array}$ & $\begin{array}{c}0.017 \\
{[0.024]}\end{array}$ \\
\hline Size of the firm & $\begin{array}{c}-0.009 \\
{[0.049]}\end{array}$ & $\begin{array}{c}-0.009 \\
{[0.059]}\end{array}$ \\
\hline Foreign owned & $\begin{array}{l}0.167^{* * *} \\
{[0.051]}\end{array}$ & $\begin{array}{l}0.152^{* *} \\
{[0.059]}\end{array}$ \\
\hline Location in Capital Region & $\begin{array}{c}0.094 \\
{[0.045]}\end{array}$ & $\begin{array}{c}0.056 \\
{[0.053]}\end{array}$ \\
\hline Country dummies & Yes & Yes \\
\hline Industry dummies & Yes & Yes \\
\hline Observations & 1186 & 1074 \\
\hline Adjusted R-squared & 0.24 & 0.40 \\
\hline \multicolumn{3}{|c|}{$\begin{array}{l}\text { Robust standard errors in parentheses. } *, * *, * * * \text { indicate } \\
\text { statistical significance at the } 10 \%, 5 \% \text { and } 1 \% \text { levels, } \\
\text { respectively. The services related variables are used in regional } \\
\text { averages. }\end{array}$} \\
\hline
\end{tabular}

It is not straightforward to interpret the order of magnitude of our estimated coefficients. However, some interesting counterfactuals are possible. For example, one can ask what would happen if a country like Zambia, situated at the lower middle of the distribution of telecommunications performance, were to move to the level of performance of South Africa, the best performer in our sample. The productivity improvement associated with such a shift would amount to $13.2 \%$, based on the results in column II of table 2 .

\section{Electric Power}

\footnotetext{
${ }^{4}$ None of the results presented in this paper is sensitive to the inclusion of export status and foreign ownership in the regressions. We tested all the estimations presented in this paper for robustness with respect to excluding these two. The estimated services coefficients and standard errors were so similar to the ones presented here that we refrained from presenting these results. They are available upon request from the authors.
} 
Turning now to the access to reliable electric power, table 3 shows a significant relationship between measures of performance and the reliability of electricity provision. The variable available in the Enterprise Surveys for this sector measures the number of days with power outages over the previous year. A particular caveat applies to this sector: faulty energy provision from the public grid does not necessarily imply that the firm had access interruptions, because producing electricity in-house using a private generator is a means of circumventing the deficiencies of electricity provision from the public grid. Given the significant scale economies in electricity production, it is clearly not a cost-effective way of providing the firm with energy, but generators can dampen the link between the reliability of power provision and firm performance. This is why we want to control in our regressions for the use of firm-owned generators.

The estimated coefficient on our outage measure is negative, and significant at the $5 \%$ level using the semi-parametrically estimated firm productivities (and negative but not significant using least squares). This means that firms in regions with more frequent power outages are less productive than others. We also find the coefficient on the share of firms that own a generator to be significant and positive. This is consistent with the interpretation that firms that are able to generate their own electricity are benefiting from the fact that the continuity of their production is decoupled from the continuity of local energy provision. In fact, our data display a strong and positive relationship between the decision to acquire a generator and the degree to which firms perceive electricity supply problematic. As shown in the appendix, a firm's perception of the difficulties in accessing reliable energy is a highly significant predictor of the firm's odds of owning a generator. This is true both at the level of firms and for regional averages. 
Table 3: Total Factor Productivity and Electricity

\begin{tabular}{|lcc|}
\hline \multicolumn{1}{|c}{ TFP estimation procedure: } & OLS & Olley/Pakes \\
\hline \hline Days with power outages & -0.002 & $-0.005^{* *}$ \\
& {$[0.002]$} & {$[0.003]$} \\
Share of firms that own a & $0.662^{* * *}$ & $0.634^{* *}$ \\
generator & {$[0.255]$} & {$[0.296]$} \\
Exporter & -0.035 & 0.021 \\
& {$[0.044]$} & {$[0.052]$} \\
Age of the firm & 0.009 & 0.029 \\
& {$[0.018]$} & {$[0.023]$} \\
Size of the firm & 0.028 & 0.041 \\
& {$[0.046]$} & {$[0.056]$} \\
Foreign owned & $0.169^{* * *}$ & $0.150^{* *}$ \\
& {$[0.053]$} & {$[0.060]$} \\
Location in Capital Region & $0.173^{* * *}$ & $0.194^{* * *}$ \\
& {$[0.051]$} & {$[0.059]$} \\
Country dummies & Yes & Yes \\
Industry dummies & Yes & Yes \\
\hline Observations & 985 & 880 \\
Adjusted R-squared & 0.30 & 0.47 \\
\hline Robust standard errors in parentheses. & $*, * * * *$ indicate \\
statistical significance at the $10 \%, 5 \%$ and $1 \%$ levels, respectively. & \\
The services related variables are used in regional averages. & & \\
& & \\
\hline
\end{tabular}

\section{Financial Services}

With respect to the financial sector, we have separate information on two key functions of banks. The first role of banks that we analyze is to facilitate payment transactions domestically and internationally. We proxy the efficiency with which payment transactions are conducted by using information from the Enterprise Surveys on the number of days required to clear both a domestic and an international payment transaction. For example, clearing a foreign currency wire takes between 3 days in Mauritius and almost 8 days in Ethiopia. Clearing a domestic currency wire takes an average of 4 days in Tanzania. While this is an admittedly specific element of banking transactions, it is likely to proxy the overall transaction efficiency of locally available banking services.

The results in table 4 show a significant positive relationship between firm productivity and the efficiency of the banking system in facilitating payment transactions, as measured by the speed of payment processing. The relationship holds regardless of whether we focus on the processing of domestic currency payments or international transactions, and regardless of which of the two productivity estimates we use. Even when the two measures are introduced together, both remain significant at the 5\% level. In other words, firms in regions where banks operate more efficiently are on average more productive than firms located in regions with low banking efficiency. ${ }^{5}$

\footnotetext{
${ }^{5}$ It should be recalled that the regressions include country and industry fixed effects, so that we are not picking up systematic differences in banking efficiency across these two dimensions.
} 
Table 4: Total Factor Productivity and Banking Sector Performance: Transaction Efficiency

\begin{tabular}{|c|c|c|c|c|c|c|}
\hline TFP estimation procedure: & $\begin{array}{c}\text { I } \\
\text { OLS }\end{array}$ & $\begin{array}{c}\text { II } \\
\text { Olley/Pakes }\end{array}$ & $\begin{array}{c}\text { III } \\
\text { OLS }\end{array}$ & $\begin{array}{c}\text { IV } \\
\text { Olley/Pakes }\end{array}$ & $\begin{array}{c}\mathrm{V} \\
\text { OLS }\end{array}$ & $\begin{array}{c}\text { VI } \\
\text { Olley/Pakes }\end{array}$ \\
\hline $\begin{array}{l}\text { Days to clear a foreign currency } \\
\text { wire }\end{array}$ & $\begin{array}{c}-0.055^{* * *} \\
{[0.017]}\end{array}$ & $\begin{array}{c}-0.074^{* * *} \\
{[0.019]}\end{array}$ & & & $\begin{array}{l}-0.042^{* *} \\
{[0.019]}\end{array}$ & $\begin{array}{c}-0.071^{* * *} \\
{[0.019]}\end{array}$ \\
\hline $\begin{array}{l}\text { Days to clear a domestic currency } \\
\text { wire }\end{array}$ & & & $\begin{array}{c}-0.123^{* * *} \\
{[0.029]}\end{array}$ & $\begin{array}{l}-0.041^{* *} \\
{[0.019]}\end{array}$ & $\begin{array}{l}-0.081^{* *} \\
{[0.032]}\end{array}$ & $\begin{array}{l}-0.036^{* *} \\
{[0.017]}\end{array}$ \\
\hline Exporter & $\begin{array}{c}0.003 \\
{[0.047]}\end{array}$ & $\begin{array}{c}0.099^{*} \\
{[0.058]}\end{array}$ & $\begin{array}{l}-0.006 \\
{[0.048]}\end{array}$ & $\begin{array}{c}0.102^{*} \\
{[0.058]}\end{array}$ & $\begin{array}{l}-0.001 \\
{[0.048]}\end{array}$ & $\begin{array}{c}0.099^{*} \\
{[0.058]}\end{array}$ \\
\hline Age of the firm & $\begin{array}{c}0.017 \\
{[0.021]}\end{array}$ & $\begin{array}{c}0.046^{*} \\
{[0.025]}\end{array}$ & $\begin{array}{c}0.015 \\
{[0.021]}\end{array}$ & $\begin{array}{c}0.043^{*} \\
{[0.026]}\end{array}$ & $\begin{array}{c}0.02 \\
{[0.021]}\end{array}$ & $\begin{array}{c}0.05^{* *} \\
{[0.025]}\end{array}$ \\
\hline Size of the firm & $\begin{array}{l}-0.001 \\
{[0.052]}\end{array}$ & $\begin{array}{c}-0.023 \\
{[0.063]}\end{array}$ & $\begin{array}{c}0.013 \\
{[0.052]}\end{array}$ & $\begin{array}{c}-0.02 \\
{[0.063]}\end{array}$ & $\begin{array}{c}0.005 \\
{[0.052]}\end{array}$ & $\begin{array}{c}-0.023 \\
{[0.063]}\end{array}$ \\
\hline Foreign owned & $\begin{array}{l}0.176^{* * *} \\
{[0.055]}\end{array}$ & $\begin{array}{l}0.156^{* *} \\
{[0.064]}\end{array}$ & $\begin{array}{l}0.186^{* * *} \\
{[0.053]}\end{array}$ & $\begin{array}{l}0.164^{* * *} \\
{[0.063]}\end{array}$ & $\begin{array}{l}0.18^{* * *} \\
{[0.054]}\end{array}$ & $\begin{array}{l}0.158^{* *} \\
{[0.064]}\end{array}$ \\
\hline Location in Capital Region & $\begin{array}{c}0.031 \\
{[0.051]}\end{array}$ & $\begin{array}{c}0.024 \\
{[0.061]}\end{array}$ & $\begin{array}{l}0.126^{* *} \\
{[0.054]}\end{array}$ & $\begin{array}{l}-0.009 \\
{[0.062]}\end{array}$ & $\begin{array}{c}0.107^{*} \\
{[0.055]}\end{array}$ & $\begin{array}{c}0.052 \\
{[0.062]}\end{array}$ \\
\hline Country dummies & Yes & Yes & Yes & Yes & Yes & Yes \\
\hline Industry dummies & Yes & Yes & Yes & Yes & Yes & Yes \\
\hline Observations & 911 & 824 & 920 & 833 & 911 & 824 \\
\hline Adjusted R-squared & 0.28 & 0.42 & 0.27 & 0.41 & 0.28 & 0.42 \\
\hline
\end{tabular}

In order to get a sense of the estimated order of magnitude of our effects, we repeat the hypothetical exercise of lifting Zambia, a country in the middle field, up to the level of South Africa. Based on the results in regression II, such an increase would bring a 5.8 percent increase in the productivity of firms in Zambia.

The second aspect of financial services we consider is the role of financial institutions in allocating savings among investment opportunities, by extending credit to firms. Being able to access credit is probably one of the most important services that a firm needs in order to optimize its investment decisions, but firms in Africa are often credit-constrained. In fact, firms in the Enterprise Surveys report access to and the cost of financing as the most severe obstacles to production and growth.

In order to evaluate the credit dimension, we have to rely on the subjective measures from the Enterprise Surveys. We use two types of proxy measures: one is the degree to which access to credit is perceived to be an obstacle for firms, averaged at the regional level. This variable measures access rather than cost. The second measure is the firms' perception about the cost of obtaining finance. Since cost may be related to how much credit is extended, we additionally choose to control for the share of firms in a given region that had an outstanding loan in these regressions. For example, there may be cases in which only a select handful of firms get access to credit and enjoy a low interest rate. 
Table 5 shows that the difficulty of accessing credit is negatively correlated with firm performance. In those regions where the average firm finds it more difficult to get a loan, firms perform less well, or, expressed differently, firms are more productive where access to credit is easier. Columns I and II use the access-related measure, and show a significant negative coefficient on the perceived difficulties of accessing credit. The estimated coefficient is negative and significant at $1 \%$ with OLS productivities and it is still significant using the Olley and Pakes productivities, although only at the $10 \%$ significance level. Regarding the perceived cost of obtaining credit in columns III and IV, our results using OLS productivities indicate that firms in regions with a higher cost of getting credit are less productive - even after controlling for the fraction of firms that have access to credit, which we find to be positively associated with firm productivity. For our productivity estimates from the Olley and Pakes procedure, we estimate the same sign on both coefficients, but the estimate on the cost of financing is not significant in this case. The share of firms in a given region that has an outstanding loan, however, comes out positive and significant in both cases, indicating that access to finance is associated with better performance.

Perhaps more than others, the regressions in table 5 are subject to a caveat regarding endogeneity. In the absence of panel data, it is difficult to address the question of causality between firm performance and access to finance in the region. There may be regions with a distinct advantage that improves the average firm productivity, and also make these regions more profitable for bank lending. Only to the extent that such regions are the countries' capital regions can we address this with the indicator variable for location in the capital region, which does not turn out to exert a significant positive influence on productivity. Hence, we prefer to interpret our results as being consistent with the argument that easier access to financing improves firm productivity rather than as proof of a causal relationship. 
Table 5: Total Factor Productivity and Banking Sector Performance: Access to credit

\begin{tabular}{|c|c|c|c|c|}
\hline TFP estimation procedure: & $\begin{array}{c}\text { I } \\
\text { OLS }\end{array}$ & $\begin{array}{c}\text { II } \\
\text { Olley/Pakes }\end{array}$ & $\begin{array}{c}\text { III } \\
\text { OLS }\end{array}$ & $\begin{array}{c}\text { IV } \\
\text { Olley/Pakes }\end{array}$ \\
\hline $\begin{array}{l}\text { Perceived difficulty of access to } \\
\text { finance }\end{array}$ & $\begin{array}{c}-0.220^{* * *} \\
{[0.068]}\end{array}$ & $\begin{array}{l}-0.133^{*} \\
{[0.076[}\end{array}$ & & \\
\hline $\begin{array}{l}\text { Perceived difficulty of cost of } \\
\text { finance }\end{array}$ & & & $\begin{array}{l}-0.171^{* *} \\
{[0.071]}\end{array}$ & $\begin{array}{l}-0.067 \\
{[0.078]}\end{array}$ \\
\hline Regional \% of firms with a loan & & & $\begin{array}{l}0.739^{* * *} \\
{[0.245]}\end{array}$ & $\begin{array}{l}0.769^{* *} \\
{[0.304]}\end{array}$ \\
\hline Exporter & $\begin{array}{c}-0.018 \\
{[0.044]}\end{array}$ & $\begin{array}{c}0.059 \\
{[0.052]}\end{array}$ & $\begin{array}{c}-0.01 \\
{[0.044]}\end{array}$ & $\begin{array}{c}0.068 \\
{[0.053]}\end{array}$ \\
\hline Age of the firm & $\begin{array}{c}0.007 \\
{[0.019]}\end{array}$ & $\begin{array}{c}0.019 \\
{[0.024]}\end{array}$ & $\begin{array}{c}0.006 \\
{[0.019]}\end{array}$ & $\begin{array}{c}0.015 \\
{[0.024]}\end{array}$ \\
\hline Size of the firm & $\begin{array}{c}0.018 \\
{[0.049]}\end{array}$ & $\begin{array}{c}0.004 \\
{[0.059]}\end{array}$ & $\begin{array}{l}0.014 \\
{[0.05]}\end{array}$ & $\begin{array}{l}-0.006 \\
{[0.06]}\end{array}$ \\
\hline Foreign owned & $\begin{array}{l}0.167^{* * *} \\
{[0.051]}\end{array}$ & $\begin{array}{l}0.146^{* *} \\
{[0.059]}\end{array}$ & $\begin{array}{l}0.166^{* * *} \\
{[0.051]}\end{array}$ & $\begin{array}{l}0.154^{* *} \\
{[0.060]}\end{array}$ \\
\hline Location in Capital Region & $\begin{array}{c}0.067 \\
{[0.044]}\end{array}$ & $\begin{array}{c}0.027 \\
{[0.052]}\end{array}$ & $\begin{array}{c}0.023 \\
{[0.047]}\end{array}$ & $\begin{array}{c}-0.024 \\
{[0.056]}\end{array}$ \\
\hline Country dummies & Yes & Yes & Yes & Yes \\
\hline Industry dummies & Yes & Yes & Yes & Yes \\
\hline Observations & 1186 & 1077 & 1186 & 1077 \\
\hline Adjusted R-squared & 0.24 & 0.40 & 0.24 & 0.40 \\
\hline
\end{tabular}

The two aspects of financial sector performance, although in principle not necessarily related, turn out to be highly correlated with each other in the data. Table A1 in the appendix shows the positive and statistically significant relationship between the number of days required to clear a foreign wire and the perceived cost of financing. In other words, in those regions where the financial sector seems to perform better, it does so both with respect to facilitating payment transactions and extending credit.

\section{Entering all three services sectors into the regressions}

In addition to entering performance measures for each service sector separately, it is also interesting to see how far our results carry through when we simultaneously enter measures of all three services sectors into the estimation of equation (2). The question here is whether we can detect a significant association between firm productivity and the performance of a given services sector, conditional on the performance of other services. Table 6 presents these results. The models in table 6 differ in the performance measures chosen for the electricity sector, for which we have two measures in table 3.

Our results for the telecommunications and banking sectors carry through in all specifications of table 6 . We find a significant positive correlation between the performance measures for these sectors and manufacturing productivity in all cases. The results for the electricity sector, 
however, are somewhat fragile. In columns I and II, we use both measures of performance for the electricity sector, as in table 3. In this specification, we find no significant results for the power sector. In columns III and IV, we find a significant negative relationship between the share of firms in the region that chose to purchase their own power generator and the productivity of manufacturing firms, but we cannot confirm this result for the number of days with power outages in a given region. The latter measure turns out to be highly correlated with the telecommunications and banking measures (with a correlation coefficient of $>0.50$ in both cases), making the simultaneous inclusion of these measures problematic. Hence, when entering all three services sectors simultaneously into the equation, we can confirm a significant relationship between productivity and the performance of telecommunications and financial services, but find inconclusive results for the electricity sector.

Table 6: Total Factor Productivity and Services Sector Performance: All

\begin{tabular}{|c|c|c|c|c|c|c|}
\hline TFP estimation procedure: & $\begin{array}{c}\text { I } \\
\text { OLS }\end{array}$ & $\begin{array}{c}\text { II } \\
\text { Olley/Pakes }\end{array}$ & $\begin{array}{c}\text { III } \\
\text { OLS }\end{array}$ & $\begin{array}{c}\text { IV } \\
\text { Olley/Pakes }\end{array}$ & $\begin{array}{c}\mathrm{V} \\
\mathrm{OLS}\end{array}$ & $\begin{array}{c}\text { VI } \\
\text { Olley/Pakes }\end{array}$ \\
\hline Days required to get a phone line & $\begin{array}{l}-0.003^{* *} \\
{[0.001]}\end{array}$ & $\begin{array}{l}-0.005^{* *} \\
{[0.002]}\end{array}$ & $\begin{array}{c}-0.006^{* * *} \\
{[0.001]}\end{array}$ & $\begin{array}{c}-0.007^{* * *} \\
{[0.001]}\end{array}$ & $\begin{array}{c}-0.004^{* * *} \\
{[0.001]}\end{array}$ & $\begin{array}{c}-0.004^{* * *} \\
{[0.002]}\end{array}$ \\
\hline $\begin{array}{l}\text { Days to clear a domestic currency } \\
\text { wire }\end{array}$ & $\begin{array}{l}-0.082^{* *} \\
{[0.035]}\end{array}$ & $\begin{array}{l}-0.120^{* * *} \\
{[0.044]}\end{array}$ & $\begin{array}{c}-0.203^{* * *} \\
{[0.034]}\end{array}$ & $\begin{array}{c}-0.264^{* * *} \\
{[0.041]}\end{array}$ & $\begin{array}{c}-0.088^{* * *} \\
{[0.032]}\end{array}$ & $\begin{array}{c}-0.116^{* * *} \\
{[0.039]}\end{array}$ \\
\hline Days with power outages & $\begin{array}{c}-0.002 \\
{[0.004]}\end{array}$ & $\begin{array}{l}-0.006 \\
{[0.005]}\end{array}$ & & & $\begin{array}{c}-0.002 \\
{[0.003]}\end{array}$ & $\begin{array}{l}-0.006 \\
{[0.004]}\end{array}$ \\
\hline Share of firms that own a generator & $\begin{array}{c}0.101 \\
{[0.292]}\end{array}$ & $\begin{array}{l}-0.072 \\
{[0.400]}\end{array}$ & $\begin{array}{c}-0.960^{* * *} \\
{[0.272]}\end{array}$ & $\begin{array}{c}-1.260^{* * *} \\
{[0.322]}\end{array}$ & & \\
\hline Exporter & $\begin{array}{l}-0.028 \\
{[0.048]}\end{array}$ & $\begin{array}{c}0.061 \\
{[0.057]}\end{array}$ & $\begin{array}{l}-0.011 \\
{[0.048]}\end{array}$ & $\begin{array}{l}0.127^{* *} \\
{[0.059]}\end{array}$ & $\begin{array}{c}-0.027 \\
{[0.047]}\end{array}$ & $\begin{array}{c}0.060 \\
{[0.056]}\end{array}$ \\
\hline Age of the firm & $\begin{array}{c}0.014 \\
{[0.021]}\end{array}$ & $\begin{array}{c}0.061^{*} \\
{[0.026]}\end{array}$ & $\begin{array}{c}0.014 \\
{[0.021]}\end{array}$ & $\begin{array}{l}0.053^{* *} \\
{[0.025]}\end{array}$ & $\begin{array}{c}0.015 \\
{[0.021]}\end{array}$ & $\begin{array}{l}0.060^{* *} \\
{[0.026]}\end{array}$ \\
\hline Size of the firm & $\begin{array}{c}-0.012 \\
{[0.047]}\end{array}$ & $\begin{array}{c}-0.001 \\
{[0.061]}\end{array}$ & $\begin{array}{c}0.011 \\
{[0.053]}\end{array}$ & $\begin{array}{c}-0.014 \\
{[0.062]}\end{array}$ & $\begin{array}{c}0.013 \\
{[0.047]}\end{array}$ & $\begin{array}{c}-0.001 \\
{[0.061]}\end{array}$ \\
\hline Foreign owned & $\begin{array}{l}0.205^{* * *} \\
{[0.056]}\end{array}$ & $\begin{array}{l}0.196^{* *} \\
{[0.065]}\end{array}$ & $\begin{array}{l}0.196^{* * *} \\
{[0.054]}\end{array}$ & $\begin{array}{l}0.172^{* * *} \\
{[0.064]}\end{array}$ & $\begin{array}{l}0.204^{* * *} \\
{[0.055]}\end{array}$ & $\begin{array}{l}0.197^{* *} \\
{[0.064]}\end{array}$ \\
\hline Location in Capital Region & $\begin{array}{l}0.282^{* * *} \\
{[0.074]}\end{array}$ & $\begin{array}{c}0.332 \\
{[0.095]}\end{array}$ & $\begin{array}{l}0.326^{* *} \\
{[0.061]}\end{array}$ & $\begin{array}{c}-0.172^{* * *} \\
{[0.064]}\end{array}$ & $\begin{array}{l}0.291^{* * *} \\
{[0.071]}\end{array}$ & $\begin{array}{l}0.325^{* * *} \\
{[0.088]}\end{array}$ \\
\hline Country dummies & Yes & Yes & Yes & Yes & Yes & Yes \\
\hline Industry dummies & Yes & Yes & Yes & Yes & Yes & Yes \\
\hline Observations & 722 & 636 & 920 & 830 & 722 & 636 \\
\hline Adjusted R-squared & 0.38 & 0.53 & 0.32 & 0.46 & 0.38 & 0.53 \\
\hline
\end{tabular}

\section{Conclusion}

Difficulty in accessing essential producer services is likely to be one of the reasons behind the sluggish performance of firms in Sub-Saharan Africa. Producer services are a vital input for the manufacturing sector, and their availability, quality and cost are likely to be relevant to the productivity of firm operations. This paper uses a representative sample of manufacturing firms from 10 Sub-Saharan African countries, comprising more than 1000 firms, to investigate the 
relationship between firm productivity and access to telecommunications, electricity and financial services. In order to minimize endogeneity problems with the measures of services performance, we exploit variation in services provision across sub-national regions. Our results show a significant and positive relationship between firm productivity and service performance in all three services sectors analyzed, and are consistent with the argument that inadequate access to essential producer services hurts African firms by undermining their productivity.

To a certain degree, the deficiencies in services provision in African countries may be related to the severity of physical conditions, but the importance of political constraints should not be underestimated. Political interest groups that obtain rents from the policy status quo may prevent the policy reforms needed for the development of the sector. In telecommunications and electricity, for example, vested interests in monopoly providers have opposed the emergence of fully competitive markets in several of the countries studied in this paper. Getting services policy right must be an essential element of any growth enhancement and poverty reduction program. Inadequate access to services cannot be accepted as one more aspect of the low levels of consumption in Africa, because access to services will help foster the private sector growth necessary to break the poverty trap. 


\section{References}

Arnold, J.M. and B. Javorcik (2005). Gifted Kids or Pushy Parents? Foreign Acquisitions and Plant Performance in Indonesia. World Bank Policy Research Paper 3597.

Arnold, J.M., B. Javorcik and A. Mattoo (2006). Does Services Liberalization Benefit Manufacturing Firms? Evidence from the Czech Republic. Forthcoming as World Bank Policy Research Paper.

Arnold, J.M. and K. Hussinger (2006). Export Behavior and Firm Productivity in German Manufacturing, Review of World Economics/Weltwirtschaftliches Archiv, 141(2):219 - 243

Bigsten, A., P. Collier, S. Dercon, M. Fafchamps, B. Gauthier, J. W. Gunning, A. Oduro, R. Oostedorp, C. Pattillo, M. Soderbom, F. Teal, and A. Zeufeck (2004). Do African Manufacturing Firms Learn from Exporting. Journal of Development Studies 40(3):115-141.

Clarke, George R.G. (2005). Beyond tariffs and quotas : why don't African manufacturers export more?, Policy Research Working Paper Series 3617, The World Bank.

Eifert, B., A. Gelb, and V. Ramachandran.(2005). Business Environment and Comparative Advantage in Africa: Evidence from the Investment Climate Data. Center for Global Development Working Paper 56.

Eschenbach, F. and B. Hoekman. (2006). Services Policy Reform and Economic Growth in Transition Economies, 1990-2004. Review of World Economics/Weltwirtschaftliches Archiv, forthcoming.

Fink, C., Mattoo, A. and C. Neagu (2005). Assessing the impact of communication costs on international trade. Journal of International Economics 67(2): 428-445.

Freund, C. and D. Weinhold (2004). The effect of the Internet on international trade. Journal of International Economics, vol. 62(1):171-189.

Mattoo, A., R. Rathindran and A. Subramanian (2006). Measuring Services Trade Liberalization and its Impact on Economic Growth: An Illustration. Journal of Economic Integration, vol. 21:64-98.

Mengistae, T. and C. Pattillo (2004). Export Orientation and Productivity in Sub-Saharan Africa. International Monetary Fund Staff Papers 51(2):327-353.

Olley, G. S. and A. Pakes (1996). The Dynamics of Productivity in the Telecommunications Equipment Industry, Econometrica, vol. 64(6):1263-97.

Pavcnik, N. (2002). Trade liberalization, Exit, and Productivity improvements: Evidence from Chilean Plants. Review of Economic Studies 69: 245-276.

Tybout, J. (2000). Manufacturing Firms in Developing Countries: How Well Do They Do, and Why? Journal of Economic Literature, vol. 38(1): 11-44.

Van Biesebroeck, J. (2005). Exporting raises productivity in Sub-Saharan African manufacturing firms. Journal of International Economics, vol. 67(2): 373-391. 
Appendix.

Correlations between objective and subjective measures of services performance

\begin{tabular}{|c|c|c|c|c|}
\hline & I & II & III & IV \\
\hline & $\begin{array}{c}\text { Telecom as an } \\
\text { obstacle (subjective) }\end{array}$ & Generator & $\begin{array}{l}\text { Regional percentage } \\
\text { of firms owning a } \\
\text { generator }\end{array}$ & $\begin{array}{l}\text { Cost of finance as an } \\
\text { obstacle (subjective) }\end{array}$ \\
\hline Delay in phone connection & $\begin{array}{c}0.001 * * * \\
(0.000)\end{array}$ & & & \\
\hline $\begin{array}{l}\text { Electricity as an obstacle } \\
\text { (subjective) }\end{array}$ & & $\begin{array}{c}0.091 * * * \\
(0.025)\end{array}$ & & \\
\hline $\begin{array}{l}\text { Electricity as an obstacle } \\
\text { (subjective) -Regional } \\
\text { mean- }\end{array}$ & & & $\begin{array}{l}0.05^{* * *} \\
(0.007)\end{array}$ & \\
\hline $\begin{array}{l}\text { Nbr. of days to clear a } \\
\text { foreign currency wire }\end{array}$ & & & & $\begin{array}{l}0.011^{* *} \\
(0.005)\end{array}$ \\
\hline Estimation & Ordered probit & Probit & 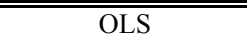 & Ordered probit \\
\hline R2/ Pseudo R2 & 0.1169 & 0.1782 & 0.82 & 0.1269 \\
\hline Observations & 756 & 2061 & 2093 & 779 \\
\hline $\begin{array}{l}\text { Robust standard errors in pa } \\
* \text { significant at } 10 \% ; * \text { sig }\end{array}$ & $\begin{array}{l}\text { theses } \\
\text { icant at } 5 \% ; * * * \text { signif }\end{array}$ & & & \\
\hline
\end{tabular}

